\title{
Mivacurium infusion requirements following vecuronium: different response between adults and children
}

The mivacurium infusion requirements following vecuronium were evaluated in 15 adults and 15 children in an open prospective clinical study. This study was undertaken to elucidate whether potentiation of effect occurred when a mivacurium infusion was administered afier vecuronium was used for the facilitation of tracheal intubation. The adult patients were anaesthetized with $\mathrm{N}_{2} \mathrm{O}: \mathrm{O}_{2}$, propofol and fentanyl, the children with halothane (1\%) $\mathrm{N}_{2} \mathrm{O}: \mathrm{O}_{2}$. Vecuronium $100 \mu \mathrm{g} \cdot \mathrm{kg}^{-\mathrm{l}}$ was administered during stimulation of the ulnar nerve with trainof-four stimuli at $0.1 \mathrm{~Hz}$. The force of contraction of the adductor pollicis was recorded. Upon recovery of the twitch response from vecuronium, a mivacurium infusion was started at $4 \mu \mathrm{g} \cdot \mathrm{kg}^{-1} \cdot \mathrm{min}^{-1}$, thereafier adjustments were made to maintain the first twitch of the train-of-four $\left(T_{1}\right)$ at $1-10 \%$ of control. The mean $( \pm S E)$ initial infusion requirements in children of mivacurium was $4.3(0.4) \mu \mathrm{g} \cdot \mathrm{kg}^{-1} \cdot \mathrm{min}^{-1}$ which increased linearly $(P<0.001)$ over the next $90 \mathrm{~min}$ to 10 $\mu \mathrm{g} \cdot \mathrm{kg}^{-1} \cdot \mathrm{min}^{-1}$. In adults the infusion requirement was lower than in children and remained at approximately 3 $\mu \mathrm{g} \cdot \mathrm{kg}^{-1} \cdot \mathrm{min}^{-1}$ over the next $75 \mathrm{~min}$. At the end of the surgical procedure, the children recovered faster than the adults with no child requiring reversal. Because of prolonged recovery $>20 \mathrm{~min}$ ), seven adults required reversal with $15-70 \mu \mathrm{g} \cdot \mathrm{kg}^{-1}$ neostigmine. Mivacurium infusion requirements following vecuronium are higher in children than adults. Potentiation of the effects of mivacurium were seen when vecuronium pre-

\section{Key words}

ANAESTHESIA: paediatric, adult;

NEUROMUSCULAR RELAXANTS: mivacurium, vecuronium; INTERACTION (DRUGS): mivacurium, vecuronium.

From the Department of Anesthesia, Massachusetts General Hospital, and Department of Anaesthesia, Harvard Medical School, Boston, MA 02114, USA.

Address correspondence to: Dr. Nishan Goudsouzain, Department of Anesthesia, Massachusetts General Hospital, Boston, MA 02114.

Accepted for publication 20th March, 1995. ceeded mivacurium. This potentiation of effect lasted longer in adults than in children.

Après l'administration de vécuronium, le besoin de mivacurium en perfusion est évalué chez 15 adultes et 15 enfants au cours d'une étude prospective ouverte. Le but de l'étude est de déterminer l'effet potentialisateur passible d'une perfusion de mivacurium à la suite de vécuronium administré pour lïntubation de la trachée. Les adultes sont anesthésiés au $\mathrm{N}_{2} \mathrm{O}: \mathrm{O}_{2}$, propofol et fentanyl, les enfants à l'halothane (1\%), $\mathrm{N}_{2} \mathrm{O}: \mathrm{O}_{2}$ Le vécuronium $100 \mu \mathrm{g} \cdot \mathrm{kg}^{-1}$ est administré pendant la stimulation du nerf cubital au train de quatre (TOF) à $0,1 \mathrm{~Hz}$. La force de contraction de l'adducteur du pouce est enregistrée. Pendant le récupération du twitch après le vécuronium, une perfusion de mivacurium est débutée à la vitesse de 4 $\mu \mathrm{g} \cdot \mathrm{kg}^{-1} \cdot \mathrm{min}^{-1}$ et par la suite elle est réglée de façon à maintenir la première contraction du TOF $\left(T_{D}\right)$ à $1-10 \%$ du contrôle. Le besoin (moyenne $\pm S D$ ) de mivacurium en perfusion chez les enfants est de $4,3(0,4) \mu \mathrm{g} \cdot \mathrm{kg}^{-1} \cdot \mathrm{min}^{-1}$ et augmente de façon linéaire $(P<0,001)$ pendant les 90 min suivantes à 10 $\mu \mathrm{g} \cdot \mathrm{kg}^{-1} \cdot \mathrm{min}^{-1}$. Chez les adultes, le besoin en perfusion est moins élevé que chez les enfants et demeure à environ 3 $\mu \mathrm{g} \cdot \mathrm{kg}^{-1} \cdot \mathrm{min}^{-1}$ pendant les $75 \mathrm{~min}$ suivantes. A la fin de l'intervention, les enfants récupèrent plus vite que les adultes et n'ont pas besoin d'antagonisme. A cause d'une récupération prolongée (>20 min), sept adultes ont eu besoin d'antagonisme avec de la néostigmine $15-70 \mu \mathrm{g} \cdot \mathrm{kg}^{-1}$. Le besoin de mivacurium en perfusion à la suite de vécuronium est plus élevé chez les enfants que chez les adultes. La potentialisation de l'effet dure plus longtemps chez les adultes que chez les enfants.

Vecuronium is a steroidal neuromuscular blocking agent that is used frequently in adults and children at a dose of $100 \mu \mathrm{g} \cdot \mathrm{kg}^{-1}$ to facilitate tracheal intubation, despite the fact that this dose is of shorter duration in children than in adults. ${ }^{1-3}$ Mivacurium, the recently available benzylisoquinolinium muscle relaxant has a shorter duration of action and is suitable for administration by infusion. The main advantage of mivacurium by infusion is that 
once the rate is established, requirements remain practically constant, with complete recovery occurring in about $20 \mathrm{~min}$ upon discontinuation of the infusion. 4-7 $^{-7}$

Previous studies have shown synergism (supra-additive effect) between competitive muscle relaxants of different chemical structures. ${ }^{8-13}$ Since mivacurium is a benzylisoquinolinium and vecuronium is a steroid, potentiation is expected between these two compounds as has been shown using onset times. ${ }^{14}$ However, the effects during maintenance of anaesthesia have not been demonstrated. Also, the increase in duration of action of mivacurium may be influenced by the action of vecuronium on plasma cholinesterase. ${ }^{15}$ Several studies have investigated the effects of the steroidal muscle relaxants on plasma cholinesterase and have demonstrated conflicting results. ${ }^{15-17}$ However, if a decrease in plasma cholinesterase did occur with the doses used in our study, then the mivacurium requirements may have been reduced.

This study was designed to evaluate the interaction of these two relaxants in a setting where vecuronium is used for intubation, and mivacurium for the continuation of the relaxation. Theoretically, this technique could exploit the clinical properties of the two relaxants. The advantages to using vecuronium for intubation are that adequate conditions are rapidly achieved with minimal cardiovascular perturbation. Then, following with a mivacurium infusion allows one to benefit from the decreased requirements of mivacurium thus an economic advantage is gained, and a finer control of relaxation is possible. A more rapid recovery of neuromuscular function may also accrue without the need for reversal. Also, this technique has the inherent safety feature of detecting early the possible potentiating effect of mivacurium by vecuronium, since the latter is begun at a low infusion rate and the adjustments would be made according to the response, therefore minimizing the risk of prolonged paralysis.

\section{Methods}

The study was approved by the Subcommittee of Human Studies of our institution and patient's or parent's consent was obtained. Thirty ASA 1 patients, 15 adults 18-62 yr of age, and 15 children 1-11 yr of age were evaluated. All patients were within $15 \%$ of their ideal body weight. Patients with neuromuscular disease or receiving drugs that effect neuromuscular response were excluded. Anaesthesia was induced in adults with propofol 1.5-3.0 $\mathrm{mg} \cdot \mathrm{kg}^{-1}$ and maintained with fentanyl, $\mathrm{N}_{2} \mathrm{O}: \mathrm{O}_{2}$. If needed for short periods, isoflurane $0.2-0.4 \%$ was used to maintain the blood pressure within a satisfactory range. Children were anaesthetized with halothane $\mathrm{N}_{2} \mathrm{O}: \mathrm{O}_{2}$ and maintained at $1 \%$ inspired halothane concentration. Routine monitoring was used; i.e., pulse oximetry, end-tidal
$\mathrm{CO}_{2}(3.7-4.8 \mathrm{kPa})$, blood pressure and electrocardiogram. The oesophageal temperature in all patients was $>35.7^{\circ} \mathrm{C}$.

Neuromuscular monitoring was performed by measuring the force of contraction of the adductor pollicis, in response to indirect stimulation of the ulnar nerve with surface electrodes. The supramaximal train-of-four stimuli $(2 \mathrm{~Hz}$ for $2 \mathrm{sec})$ were repeated every 10 seconds. The force of contraction was measured by a Grass transducer (FT-10 in adults, FT-03 in children) and recorded by a Grass polygraph.

Following induction of anaesthesia, a stable neuromuscular response was obtained and vecuronium 100

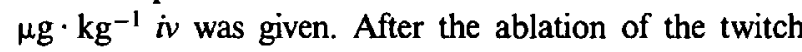
response, tracheal intubation was performed. Upon neuromuscular recovery to $\mathrm{T}_{1}>10 \%$ of control, an infusion of mivacurium $\left(500 \mu \mathrm{g} \cdot \mathrm{ml}^{-1}\right)$ was started at 4 $\mu \mathrm{g} \cdot \mathrm{kg}^{-1} \cdot \mathrm{min}^{-1}$. Thereafter the infusion rate was adjusted to maintain $T_{1}$ at $1-10 \%$ of control. At the end of the surgical procedure the mivacurium infusion was discontinued and the neuromuscular response was allowed to recover spontaneously. If, $20 \mathrm{~min}$ after the discontinuation of infusion, the train-of-four ratio was less than $75 \%$, glycopyrrolate $10 \mu \mathrm{g} \cdot \mathrm{kg}^{-1}$ and neostigmine $15-75 \mu \mathrm{g} \cdot \mathrm{kg}^{-1}$ were administered.

The mivacurium infusion requirements and the corresponding $T_{1} /$ control responses were analyzed every three minutes. Means, SD and SE were calculated using standard formulae. Data are presented as mean (SE). To compare the recovery variables from vecuronium and $\mathrm{mi}-$ vacurium betweeen adults and children, t-test and analysis of variance were used. To compare the infusion requirements, analysis of variance was performed using a general linear model (proc GLM, SAS version 6.04, Cary NC). The model included subject, time and subject by time interaction.

\section{Results}

The mean $( \pm \mathrm{SE})$ age of the children studied was 5.7 (0.9) $\mathrm{yr}$, range 1-11 yr, and their weight was 23.8 (13.4) $\mathrm{kg}$, range $12-55 \mathrm{~kg}$. The mean age of the adults was 47 (4) $\mathrm{yr}$, range 18-62 $\mathrm{yr}$ and their weight $77(3.3) \mathrm{kg}$, range $65-100 \mathrm{~kg}$. There was no difference in the recovery of $\mathrm{T}_{1}$ from the initial dose of vecuronium to $5 \%$ of control between children (27 (6.2 min)) and adults (34.7 (2.1)). Fifteen minutes were required following the start of the mivacurium infusion to obtain a stable twitch response. At 15 min of infusion time, the mivacurium requirement for children was $4.3(0.4) \mu \mathrm{g} \cdot \mathrm{kg}^{-1} \cdot \mathrm{min}^{-1}$ for a $\mathrm{T}_{1} 6.9$ (1.2)\% of control. In adults the infusion requirement was $2.9(0.3) \mu \mathrm{g} \cdot \mathrm{kg}^{-1} \cdot \mathrm{min}^{-1}$ for a $\mathrm{T}_{1} 5.1(1.9) \%$ of control (Figure). Analysis with repeated measures ANOVA showed a rapid increase in the infusion requirements of 


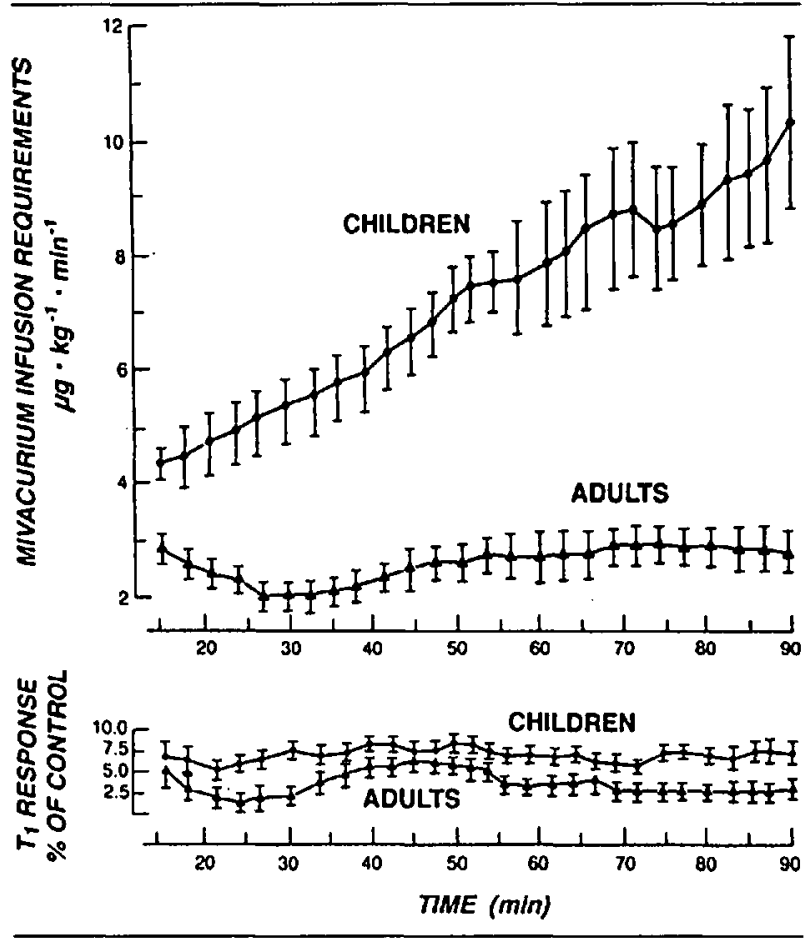

FIGURE Mivacurium infusion requirements and corresponding twitch responses (mean (SE)) following $100 \mu \mathrm{g} \cdot \mathrm{kg}^{-1}$ vecuronium. Adults were anaesthetized with propofol, $\mathrm{N}_{2} \mathrm{O}: \mathrm{O}_{2}$, fentanyl, children with halothane (1\%), $\mathrm{N}_{2} \mathrm{O}: \mathrm{O}_{2}$

children (slope $0.079, P<0.0001$ ). Only a mildly increasing infusion requirement was noted in adults at the 25-75 min infusion time (slope $0.008, P<0.0001$ ). The difference in slope of the curves was such that after 60 $\min$, the infusion requirement was about 2.5 times greater in children than in adults, i.e., $7.8(0.8) \mu \mathrm{g} \cdot \mathrm{kg}^{-1} \cdot \mathrm{min}^{-1}$ in children and $2.7(0.3) \mu \mathrm{g} \cdot \mathrm{kg}^{-1} \cdot \mathrm{min}^{-1}$ in adults. Throughout the study the infusion requirement was higher in children than in adults despite the fact that there was no difference in the twitch responses $\left(\mathrm{T}_{1} /\right.$ control) between adults and children $(\mathrm{F}=1.4, P=0.25)$ (Figure).

Despite the higher rates of infusion, children recovered faster than adults. At discontinuation of infusion, $T_{1} /$ control recovered to $25 \%$ in $4.1(0.8) \mathrm{min}$ in children, whereas adults recovered to the same twitch height in $10.9(1.7) \mathrm{min}(P<0.01)$. The recovery of the trainof-four ratios to $75 \%$ occurred in $15.9(0.9) \mathrm{min}$ in children (Table I). In the eight adults, who recovered spontaneously, recovery of train-of-four to $75 \%$ occurred in $30.6(5.8) \min (P<0.05)$. In the other seven adults, because of prolonged recovery $(>20 \mathrm{~min})$, reversal of the neuromuscular effect of relaxants was needed. In these, $T_{1}$ had recovered to 49 (9)\% of control in 25 (5) min following discontinuation of infusion. After 45 (7)
TABLE I The recovery variables (mean $\pm \mathrm{SE}$ ) of mivacurium infusion following vecuronium $\left(0.1 \mathrm{mg} \cdot \mathrm{kg}^{-1}\right)$ in adults and children (Adults were anaesthetized by $\mathrm{N}_{2} \mathrm{O}: \mathrm{O}_{2}$ narcotic, children $\mathrm{N}_{2} \mathrm{O}: \mathrm{O}_{2}$; halothane $1 \%$ )

\begin{tabular}{llrl}
\hline & $\begin{array}{l}\text { Adults } \\
(n=15) \\
(\mathrm{min})\end{array}$ & $\begin{array}{l}\text { Children } \\
(n=15) \\
(\mathrm{min})\end{array}$ & $P$ \\
\hline $\begin{array}{l}\text { Duration of miva- } \\
\text { curium infusion }\end{array}$ & $133.7 \pm 14.5$ & $121 \pm 16.1$ & NS \\
$\begin{array}{l}\quad \\
\mathrm{T}_{1} \text { at discontinuation } \\
\quad \text { of infusion }\end{array}$ & $3.1 \pm 0.5 \%$ & $4.7 \pm 2.6 \%$ & $\mathrm{NS}$ \\
$\begin{array}{l}\text { Recovery of } \\
-\mathrm{T}_{1} \text { to } 25 \% \text { of control }\end{array}$ & $10.9 \pm 1.7(n=14)$ & $4.1 \pm 0.8$ & $<.01$ \\
$-\mathrm{T}_{1}: \mathrm{T}_{4}$ to $75 \%$ & $30.6 \pm 5.8(n=7)$ & $15.9 \pm 0.9$ & $<.05$ \\
$\begin{array}{l}\text { Recovery index } \\
-25-75 \%\end{array}$ & $11.3 \pm 2.2(n=9)$ & $7 \pm 3.7$ & $=\mathrm{NS}$ \\
$-5-95 \%$ & $22.4 \pm 3.2(n=8)$ & $13.8 \pm 6.5$ & $=\mathrm{NS}$ \\
\hline
\end{tabular}

$\mu \mathrm{g} \cdot \mathrm{kg}^{-1}$ neostigmine, $\mathrm{T}_{1}$ recovered to $95 \%$ of control in an additional $5.5(2.1) \mathrm{min}$.

\section{Discussion}

A clinical advantage may accrue by following an intermediate-acting muscle relaxant with a short-acting one, enabling the anaesthetist to regulate, to a finer degree, the depth and duration of neuromuscular block during surgery. We investigated the practicality of such a technique by using the possible interaction between vecuronium and mivacurium in adults and children, and demonstrated that synergism occurs with vecuronium and mivacurium, when mivacurium is given during the recovery phase from vecuronium. This synergism was much more pronounced in adults than in children.

Previous studies in adults and children, using mivacurium as the sole relaxant, have reported a much higher infusion requirement to achieve a comparable degree of neuromuscular depression than we noted in this study, where the mivacurium infusion was given following an intubating dose of vecuronium. ${ }^{4-7}$ In adults, when mivacurium is the sole relaxant used, the infusion requirements are $6-8 \mu \mathrm{g} \cdot \mathrm{kg}^{-1} \cdot \min ^{-1}, 6,7$ whereas in this study they were $2-3 \mu \mathrm{g} \cdot \mathrm{kg}^{-1} \cdot \mathrm{min}^{-1}$. In children, when mivacurium was used alone, the dose range was 10-14 $\mu \mathrm{g} \cdot \mathrm{kg}^{-1} \cdot \min ^{-1}$, whereas in this study we started the infusion at $4 \mu \mathrm{g} \cdot \mathrm{kg}^{-1} \cdot \mathrm{min}^{-1}$ and increased to 8 $\mu \mathrm{g} \cdot \mathrm{kg}^{-1} \cdot \min ^{-1}$ over $75 \mathrm{~min} .4,5$ However, in both children and adults the decreased requirements for the mivacurium infusion lasted longer than the expected effect of the initial $100 \mu \mathrm{g} \cdot \mathrm{kg}^{-1}$ of vecuronium.

Neuromuscular blocking drugs may act at one or more of the four sites in the neuromuscular junction, i.e., the prejunctional and postjunctional acetylcholine receptor sites and their corresponding ion channels. ${ }^{18}$ Conse- 
quently, potentiation may be the result of binding at several sites. ${ }^{19,20}$ Consequently, a decrease in prejunctional stimuli and an increase in the post-junctional threshold should reinforce each other. ${ }^{18,21-23}$ Sodium channel block may also occur at the neuromuscular junction and since all muscle relaxants are cations this mechanism may contribute to the effects of the relaxants. ${ }^{24}$

The exact cause of potentiation between two muscle relaxants is unknown, but the fact that it occurs in the isolated nerve muscle preparation (in vitro), and that it occurs in the isolated arm, indicates that it is a phenomenon occurring at the myoneural junction. ${ }^{11,19,25,26}$ In vitro experiments have shown that this is due to potentiation arising at the neuromuscular junction and not just chance interactions of secondary effects of drugs involved. ${ }^{25}$ It has been suggested that the two $\alpha$-subunits of the postsynaptic acetycholine receptor have different dissociation constants. ${ }^{20,27,28}$ The shape of the agonist dose response curve of the acetylcholine receptor is systemically sigmoid; therefore, the two agonist molecules contribute to channel opening. ${ }^{27,29,30}$ This is supported by the finding that there are two primary binding sites on each receptor. Selective blocking of one of the receptor sites results in a large decrease, by an order to 20 times, in the ion transport. ${ }^{29}$ Therefore, during administration of a different relaxant when one receptor is occupied, the occupation of the other receptor may cause a further decrease in ion transport. Finally, since both $\alpha$ subunits have to be activated to open the channel, the two drugs might bind to the alpha subunits with different affinities. ${ }^{20,28}$

The interesting observation of this study was the difference in response between children and adults. The infusion requirement of children to maintain a constant neuromuscular block increased gradually, whereas in adults it remained nearly unchanged (Figure). This is probably due to the shorter duration of action of vecuronium in children than in adults. This shorter duration of action of vecuronium in children relative to adults is due to shorter mean residence time, $34.8(0.8) \mathrm{min}$ in children and 52 (7.2) $\mathrm{min}$ in adults. ${ }^{31}$ Also, a reason for the difference may be due to differences in the effective dose of vecuronium in children $\left(E_{95} 77 \mathrm{~kg} \cdot \mathrm{kg}^{-1}\right)$ compared with adults $\left(\mathrm{ED}_{95} 55 \mu \mathrm{g} \cdot \mathrm{kg}^{-1}\right){ }^{32}$ In this study, we elected to use a standard dose of vecuronium (100 $\mu \mathrm{g} \cdot \mathrm{kg}^{-1}$ ) that is used in adults and in children. In spite of the differences in $\mathrm{ED}_{95}$ the difference in recovery to $5 \%$ of control was not different between adults and children, but there was a tendency to faster recovery in children.

Our results in children with vecuronium followed by mivacurium are similar to the results that we have obtained when using atracurium for intubation and then mivacurium ${ }^{33}$ (Table II). Both studies were conducted
TABLE II Comparison of mivacurium infusion following atracurium $0.5 \mathrm{mg} \cdot \mathrm{kg}^{-1}$ and vecuronium $0.1 \mathrm{mg} \cdot \mathrm{kg}^{-1}$ in children anesthetized with halothane $\mathrm{N}_{2} \mathrm{O}: \mathrm{O}_{2}$

\begin{tabular}{lrr}
\hline & Atracurium & Vecuronium \\
\hline Mivacurium infusion & & \\
requirement $\mu \mathrm{g} \cdot \mathrm{kg}^{-1} \cdot \mathrm{min}^{-1}$ & & \\
- at $15 \mathrm{~min}$ & $3.7 \pm 0.3$ & $4.3 \pm 0.4$ \\
- at $60 \mathrm{~min}$ & $6.3 \pm 0.6$ & $7.0 \pm 0.8$ \\
- at $90 \mathrm{~min}$ & $7.4 \pm 0.8$ & $10.1 \pm 2$ \\
Recovery indices & & \\
- 25-95\% & $5.2 \pm 0.2$ & $7 \pm 3.7$ \\
- 5-95\% & $12.4 \pm 0.5$ & $13.8 \pm 6.5$ \\
\hline
\end{tabular}

*No difference between the two groups. The atracurium data are from a similar study in children conducted by the same authors using identical techniques. ${ }^{33}$

with the same anaesthetic and investigational techniques by the same group of investigators. Atracurium and mivacurium are both benzylisoquinolium compounds and potentiation was not expected between the two drugs. As in the study by Jalkanen $e t$ al. we noted synergy with an atracurium and mivacurium combination. 14,33 With atracurium, we speculated that the drug administered first played a dominiant role because most of the receptors were already occupied by atracurium $(75-80 \%$ according to the margin of safety theory, Waud). ${ }^{10,19}$ Consequently, the subsequent administration of mivacurium behaved like atracurium in the initial phase. ${ }^{33}$ Another issue concerning potentiation is the concept that the nondepolarizing muscle relaxants exist in a biophase in the area of the myoneural junction. Feldman proposed a binding compartment in the vicinity of the receptor to explain the continued action of a relaxant once the plasma concentration of the drug was diminished. ${ }^{34-36}$ This biophase binding compartment is implicated in potentiation by using a cross-over design isolated forearm experiment. In this preparation if the second relaxant is given at a twitch recovery of $50 \%$ the recovery rate of the second drug is markedly effected. This is in spite of the fact that the plasma levels of the first drug are minimal.

Obviously, the difference in anesthetic techniques used between the children and adults might have contributed to different findings. However, one would expect that halothane would decrease the requirements of mivacurium, due to the actions of potent inhalational agents. If this is considered, the differences in infusion rates would have been greater than we demonstrated.

In conclusion, we demonstrated that mivacurium infusion can be administered during the recovery phase from vecuronium. However, clinicians must realize that potentiation will occur and should be aware that the infusion requirement will remain relatively low in adults 
for at least two hours. In children, however, mivacurium requirements will progressively increase over the same time course if the level of neuromuscular block is to be maintained. In .employing this technique, the potential adverse sequelae of synergism are reduced, as the effects of potentiation are seen early and a decreased infusion rate may be employed.

\section{Acknowledgments}

The authors would like to express their sincere appreciation to Mr. Ralph D'Agostino, M.S., for performing the statistical analysis of this study and Ms. Mary Farr for her secretarial support.

\section{References}

1 Debaene $B$, Meistelman $C$, d'Hollander $A$. Recovery from vecuronium neuromuscular blockade following neostigmine administration in infants, children, and adults during halothane anesthesia. Anesthesiology 1989; 71: 840-4.

2 Ferres CJ, Crean PM, Mirakhur RK. An evaluation of Org NC 45 (vecuronium) in paediatric anaesthesia. Anaesthesia 1983; 38: 943-7.

3 Muchhal KK, Viby-Mogensen J, Fernando PUE, Tamilarasan A, Bonsu AK, Lambourne A. Evaluation of intense neuromuscular blockade caused by vecuronium using posttetanic count (PTC). Anesthesiology 1987; 66: 846-9.

4 Brandom BW, Sarner JB, Woelfel SK, et al. Mivacurium infusion requirements in pediatric surgical patients during nitrous oxide-halothane and during nitrous oxide-narcotic anesthesia. Anesth Analg 1990; 71: 16-22.

5 Alifimoff JK, Goudsouzain NG. Continuous infusion of mivacurium in children. Br J Anaesth 1989; 63: 520-4.

6 Ali $H H$, Savarese JJ, Embree PB, et al. Clinical pharmacology of mivacurium chloride (BW B1090U) infusion: comparison with vecuronium and atracurium. $\mathrm{Br} \mathrm{J}$ Anaesth 1988; 61: 541-6.

7 Basta SJ. Clinical pharmacology of mivacurium chloride: a review. J Clin Anesth 1992; 4: 153-63.

8 Mirakhur RK, Gibson FM, Ferres CJ. Vecuronium and $d-$ tubocurarine combination: potentiation of effect. Anesth Analg 1985; 64: 711-4.

9 Lebowitz PW, Ramsey RM, Savarese JJ, Ali HH. Potentiation of neuromuscular blockade in man produced by combinations of pancuronium and metocurine or pancuronium and $d$-tubocurarine. Anesth Analg 1980; 59: 604-9.

10 Waud BE, Waud DR. Quantitative examination of the interaction of competitive neuromuscular blocking agents on the indirectly elicited muscle twitch. Anesthesiology 1984; 61: 420-7.

11 Pollard BJ, Jones RM. Interactions between tubocurarine, pancuronium and alcuronium demonstrated in the rat phrenic nerve-hemidiaphragm preparation. $\mathrm{Br} \mathrm{J}$ Anaesth 1983; 55: 1127-32.
12 Rashkousky OM, Agoston S, Ket JM. Interaction between pancuronium bromide and vecuronium bromide. $\mathrm{Br} \mathrm{J}$ Anaesth 1985; 57: 1063-6.

13 Meretoja OA, Brandom BW, Taivainen T, Jalkanen $L$. Synergism between atracurium and vecuronium in children. Br J Anaesth 1993; 71: 440-2.

14 Jalkanen L, Meretoja OA, Taivainen T, Brandom BW, Dayal $B$. Synergism between atracurium and mivacurium compared with that between vecuronium and mivacurium. Anesth Analg 1994; 79: 998-1002.

15 Popovic L, Kunec-Vajic E. Plasma cholinesterase inhibition by pancuronium and vecuronium. Lijec Vjesn 1990; 112: 142-3.

16 Stovner J, Oftedal N, Holmboe. The inhibition of cholinesterases by pancuronium. Br J Anaesth 1975; 47: 949-54.

17 Mirakhur RK, Ferres CJ, Lavery TD. Plasma cholinesterase levels following pancuronium and vecuronium. Acta Anaesthesiol Scand 1983; 27: 451-3.

18 Wessler I. Pre-synaptic neuromuscular block. Anesthetic Pharmacology Review 1993; 1: 69-76.

19 Waud $B E$, Waud $D R$. Interaction among agents that block end-plate depolarization competitively. Anesthesiology 1985; 63: 4-15.

20 Neubig $R R$, Cohen $J B$. Equilibrium binding of $\left[{ }^{3} \mathrm{H}\right]$ tubocurarine and $\left[{ }^{3} \mathrm{H}\right]$ acetylcholine by torpedo postsynaptic membrane: Stoichiometry and ligand interactions. Biochemistry $1979 ; 18$ : 5464-75.

21 Bowman WC. Pharmacology of Neuromuscular Function, 2nd ed. London: Wright, 1990; 171-2.

22 Bowman WC. Prejunctional and postjunctional cholinoceptors at the neuromuscular junction. Anesth Analg. 1980; 59: 935-43.

23 Standaert FG. Release of transmitter at the neuromuscular junction. Br J Anaesth 1982; 54: 131-45.

24 Standaert FG. Donuts and holes: molecules and muscle relaxants. Seminars in Anesthesia 1984; 3: 251-61.

25 Van Der Spek AFL, Zupan JT, Pollard BJ, Schork MA. Interactions of vecuronium and atracurium in an in vitro nerve-muscle preparation. Anesth Analg 1988; 67: 240-6.

26 Taylor $P$. Are neuromuscular blocking agents more efficacious in pairs? (Editorial). Anesthesiology 1985; 63: 1-3.

27 Sine SM, Taylor P. Relationship between reversible antagonist occupancy and the functional capacity of the acetylcholine receptor. J Biol Chem 1981; 256: 6692-9.

28 Weiland $G$, Taylor $P$. Ligand specificity of state transitions in the cholinergic receptor: behaviour of agonists and antagonists. Mol Pharmacol 1979; 15: 197-212.

29 Changeux J-P, Devillers-Thiéry A, Chemouilli P. Acetylcholine receptor: an allosteric protein. Science 1984; 225: 1335-45.

30 Taylor $P$, Brown RD, Johnson DA. The linkage between ligand occupation and response of the nicotinic acetylcho- 
line receptor. Current Topics in Membranes and Transport 1983; 18: 407-44.

31 Fisher DM, Castagnoli K, Miller RD. Vecuronium kinetics and dynamics in anesthetized infants and children. Clin Pharmacol Ther 1985; 34: 402-6.

32 Meretoja OA, Wirtavuori K, Neuvonen PJ. Agedependence of the dose-response curve of vecuronium in pediatric patients during balanced anesthesia. Anesth Analg 1988; 67: 21-6.

33 Goudsouzian NG, Denman W, Matta E. Mivacurium after atracurium in children. Anesth Analg 1994; 79: 345-9.

34 Feldman $S$. Biophase binding: its effect on recovery from non-depolarizing neuromuscular block. Anesthetic Pharmacology Review 1993; 1: 81-8.

35 Feldman SA, Fauvel NJ, Hood JR. Recovery from pancuronium and vecuronium administered simultaneously in the isolated forearm and the effect on recovery following administration after cross-over of drugs. Anesth Analg 1993; 76: 92-5.

36 Feldman S, Fauvel $N$. Potentiation and antagonism of vecuronium by decamethonium. Anesth Analg 1993; 76: $631-4$. 